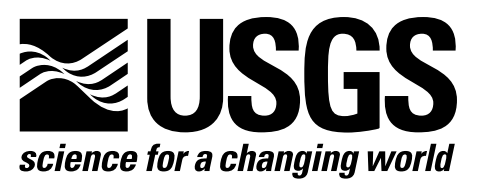

\title{
Assessment of Hazards Associated with the Bluegill Landslide, South-Central Idaho
}

\author{
By William L. Ellis, Robert L. Schuster, and William H. Schulz
}

\section{U.S. Geological Survey Open-File Report 2004-1054}




\section{Abstract}

The Bluegill landslide, located in south-central Idaho, is part of a larger landslide complex that forms an area in the Salmon Falls Creek drainage named Sinking Canyon. Recent movement of the Bluegill landslide, apparently beginning sometime in late 1998 or early 1999, has caused a 4.5 ha area of the canyon rim to drop as much as $8 \mathrm{~m}$ and move horizontally several meters into the canyon. Upward movement of the toe of the landslide in the bottom of the canyon has created a dam that impounds a lake approximately $2 \mathrm{~km}$ in length. The landslide is on public property administered by the U.S. Bureau of Land Management (BLM). As part of ongoing efforts to address possible public safety concerns, the BLM requested that the U.S. Geological Survey (USGS) conduct a preliminary hazard assessment of the landslide, examine possible mitigation options, and identify alternatives for further study and monitoring of the landslide. This report presents the findings of that assessment based on a field reconnaissance of the landslide on September 24, 2003, a review of data and information provided by BLM and researchers from Idaho State University, and information collected from other sources.

\section{Introduction}

The Bluegill landslide (fig. 1), also referred to as the Salmon Falls landslide, is located approximately $35 \mathrm{~km}$ west of Twin Falls, Idaho, and about $10 \mathrm{~km}$ west of the town of Buhl, Idaho (fig. 2). The landslide is on the east rim of a 120-mdeep canyon formed by Salmon Falls Creek (fig. 3), which

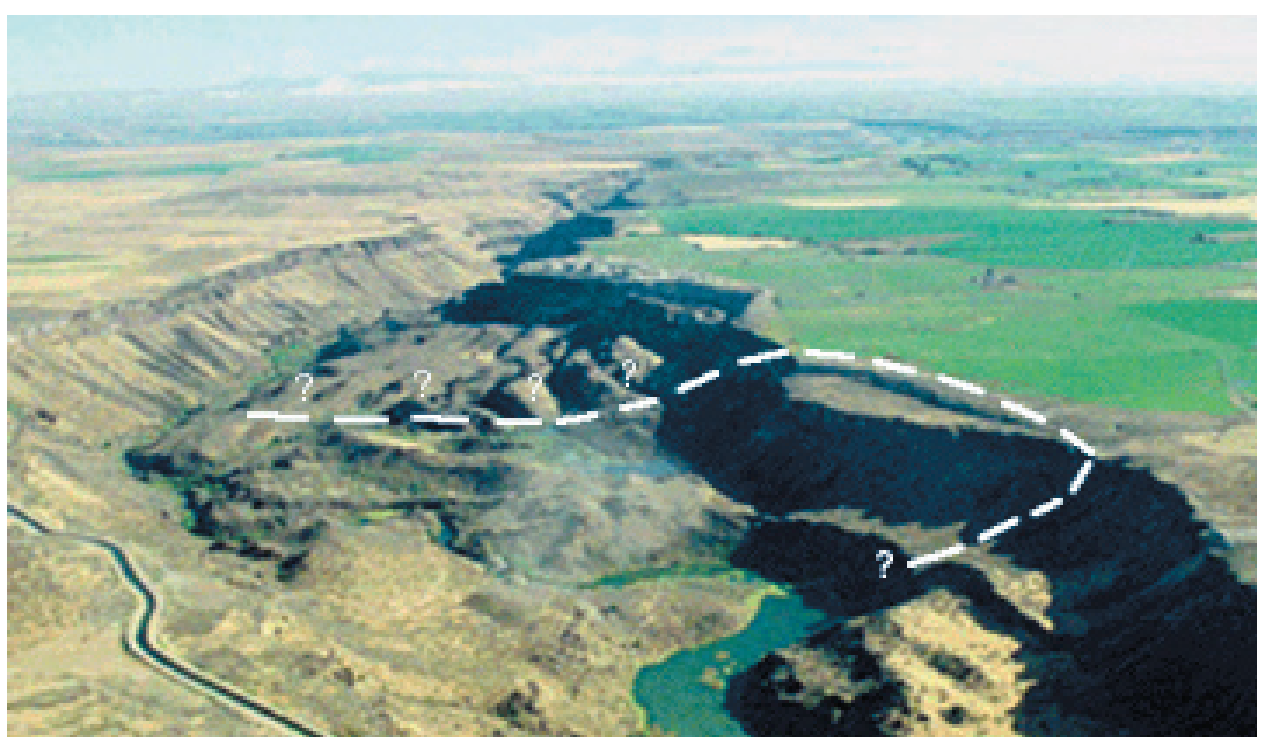

Figure 1. Oblique aerial photo of Sinking Canyon taken in March 2001, showing Sinking Canyon, Salmon Falls Creek, and Bluegill landslide. View is to the north. Approximate boundaries of the Bluegill landslide are shown by dashed line. Confluence of Salmon Falls Creek with the Snake River is approximately $10 \mathrm{~km}$ north of the landslide site. Photo courtesy of Karen Shilling, BLM. flows from south to north and merges with the Snake River approximately $12 \mathrm{~km}$ downstream from the landslide site. The landslide occurs predominantly on public property administered by the U.S. Bureau of Land Management (BLM), although portions of the landslide are on state and private property. Recent movement of the landslide was first brought to the attention of BLM officials in 1999 when recreational rock climbers noted the formation and widening of fractures in the basalt cliffs that make up the canyon rim. Since that time, the landslide has been monitored by BLM, with assistance provided by the U.S. Geological Survey (USGS) and by investigators from Idaho State University.

Since late 1999, the landslide has moved several meters in what appears to be a classic rotational type of slope failure (Varnes, 1978). The toe of the landslide has moved both horizontally and upward about equal amounts, the central portion has moved primarily horizontally in the downslope direction, and the head of the slide, which includes a portion of the canyon rim, has moved downward and horizontally about equal amounts. The upward component of motion at the toe of the slide has formed a landslide dam in Salmon Falls Creek, which has impounded a lake estimated to contain about $325,000 \mathrm{~m}^{3}$ of water. Other estimates place the lake volume as high as 1,000,000 $\mathrm{m}^{3}$ (Chadwick and others, in press).

In June 2003, the USGS was contacted by a representative of the BLM and requested to provide an evaluation and assessment of the hazards posed by the Bluegill landslide. The BLM was primarily concerned about the potential hazard posed by possible failure of the landslide dam. In response to this request, the authors of this report visited the landslide site on September 24, 2003. During the site visit, they were accompanied by Karen Shilling and Forrest Griggs of the BLM, and Glenn Thackray and Stephen Dorsch from Idaho State University. Investigators from Idaho State University have been conducting remote-sensing studies of the landslide over the past year. They have also taken over periodic surveying of landslide movement from the BLM and are in the process of doing detailed mapping of the landslide. The site inspection also included Dr. Robert Holtz from Washington State University who was retained by BLM to provide a separate assessment of the landslide situation. This report presents the findings of the USGS authors based on the site visit and 
review of other available data and information concerning the landslide.

Much of the information contained in this report was made available by the BLM, and is presented here in the same form as provided to the authors. Other information and data were obtained from World Wide Web sites. These diverse sources of information and the desire to present information in its original form have resulted in use of both metric and English units in this report. Metric conversions are provided where data plots are presented in English units.

\section{Description of Landslide}

The Bluegill landslide occurs on the southern end of a relatively wide section of the Salmon Falls Creek canyon, named Sinking Canyon (fig. 3). Sinking Canyon has been formed by progressive failure of the eastern wall

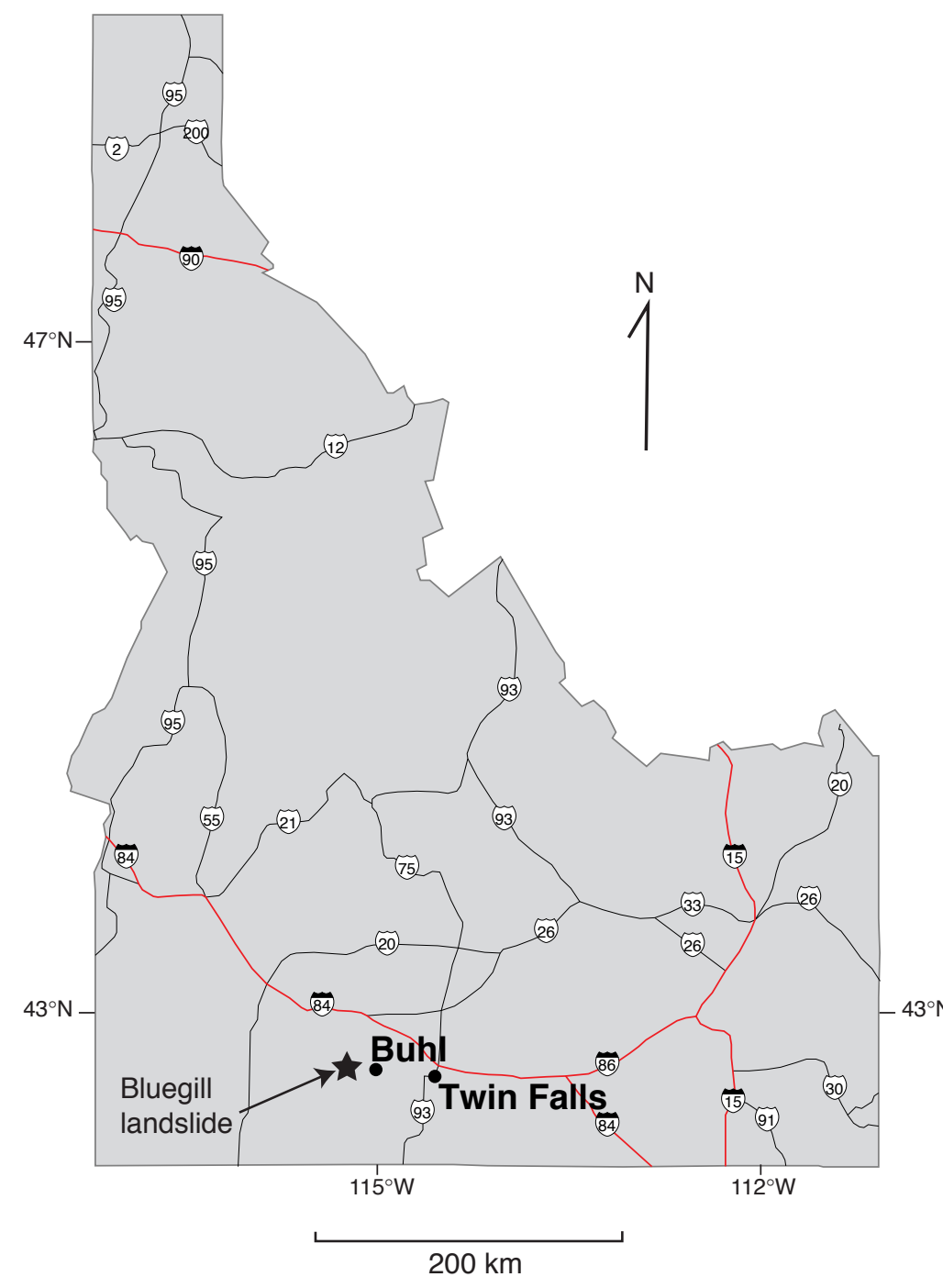

Figure 2. Index map of Idaho. Star shows location the Bluegill landslide. of the canyon, which resulted in widening of the canyon, and deposition of pre-historic landslide deposits that now cover the canyon floor. The last major landslide movements in Sinking Canyon apparently occurred in the summer of 1937 when several acres of farmland were lost over a period of several days by "sinking" (i.e., landslide movement) into the existing canyon. An examination of early newspaper accounts and a scientific paper by Lee (1938) indicate that the area of the canyon rim lost to landslide activity was relatively small compared to the canyon width, and that landslide movement caused adjustments of the stream channel and at least one small landslide dam. The 1937 Sinking Canyon episode was likely a continuation of mass-wasting processes that have occurred in this area since the inception of the canyon. The Bluegill landslide is the southern extension of the Sinking Canyon landslide complex. Old fractures located behind the current Bluegill landslide headscarp indicate that some extensional deformation occurred in this area in the past. These fractures may have formed at the time of the 1937 landsliding, but without the large amount of movement that took place just to the north of the present landslide area.

There has been some speculation that an earthquake felt in the Buhl area in 1934 (The Buhl Herald, March 15, 1934) may have produced fracturing behind the canyon rim that weakened the canyon wall and ultimately resulted in the 1937 landsliding episode. That earthquake is listed in the Utah historic earthquake catalogue (www.seis.utah.edu/Reports/ UtahHistoricEqCat1850-1962) as a magnitude 6.6 with the epicenter in north central Utah. Although the earthquake was felt in the Buhl, Idaho, area, little damage was reported and there is no direct evidence to link the earthquake to later landsliding activity.

The Bluegill landslide consists of an approximately 4.5 ha area of the upper canyon rim, and a larger portion of uncertain size within the older landslide deposits that cover the lower part of the canyon (fig. 4). The southern lateral boundary of the active slide appears to be expressed as a series of stepping extensional fractures that extend from the base of the basalt cliff at the head of the slide to the bank of Salmon Falls Creek. The northern lateral boundary of the slide is not clearly discernible because basalt boulders and unconsolidated material cover the slope. The northern boundary depicted on figure 4 is speculative and is based on limited observation of disrupted and fractured slide debris in a few locations.

The overall movement of the slide has resulted in down dropping and westward movement of the canyon rim, and westward and upward motion at the toe of the slide in the canyon bottom. The maximum downward movement of the canyon rim is at the north end of the landslide, with displacement 


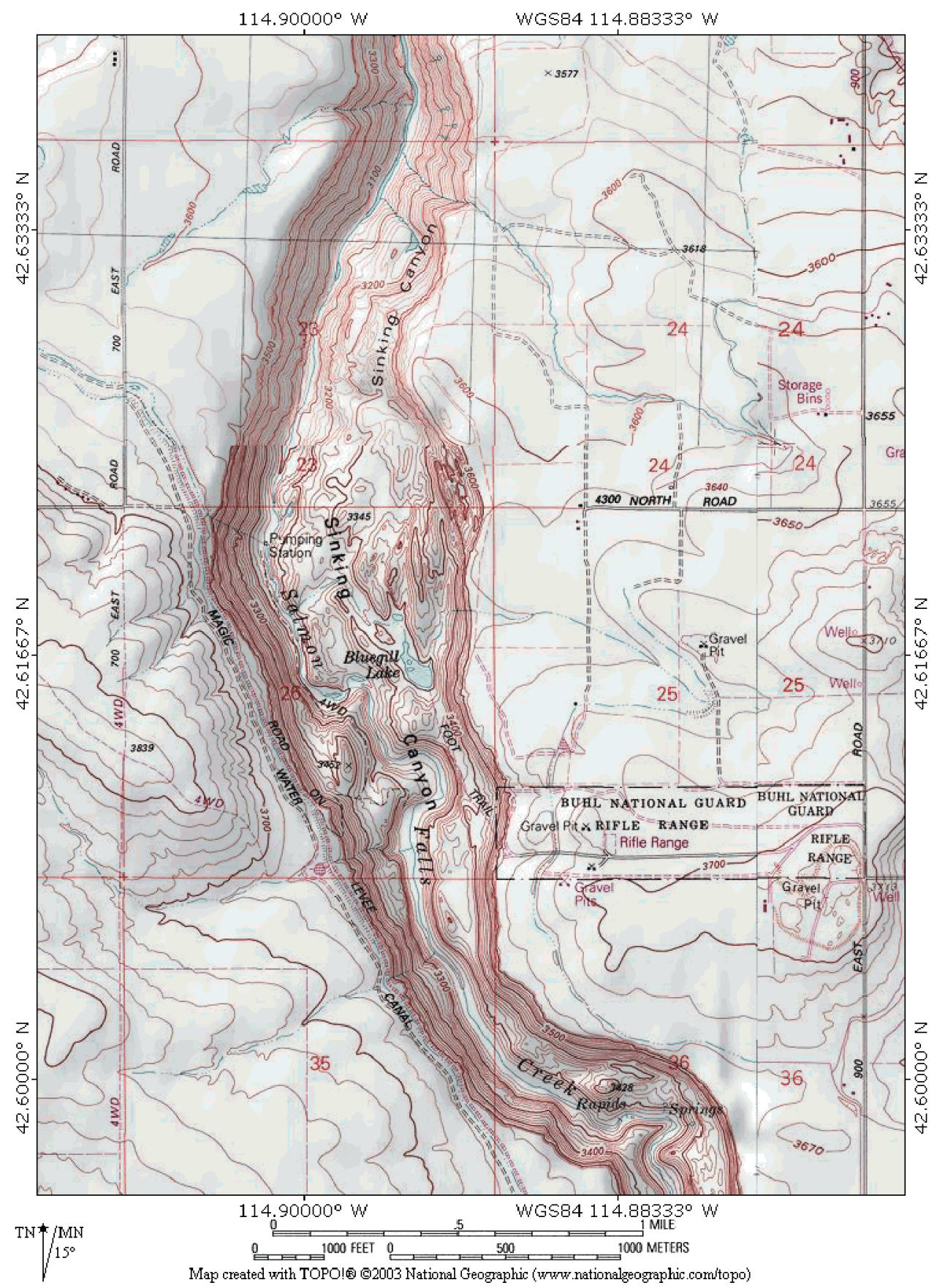

Figure 3. Topographic map showing Sinking Canyon and Salmon Falls Creek (Balanced Rock 7.5-minute Quadrangle, USGS, 1987). 

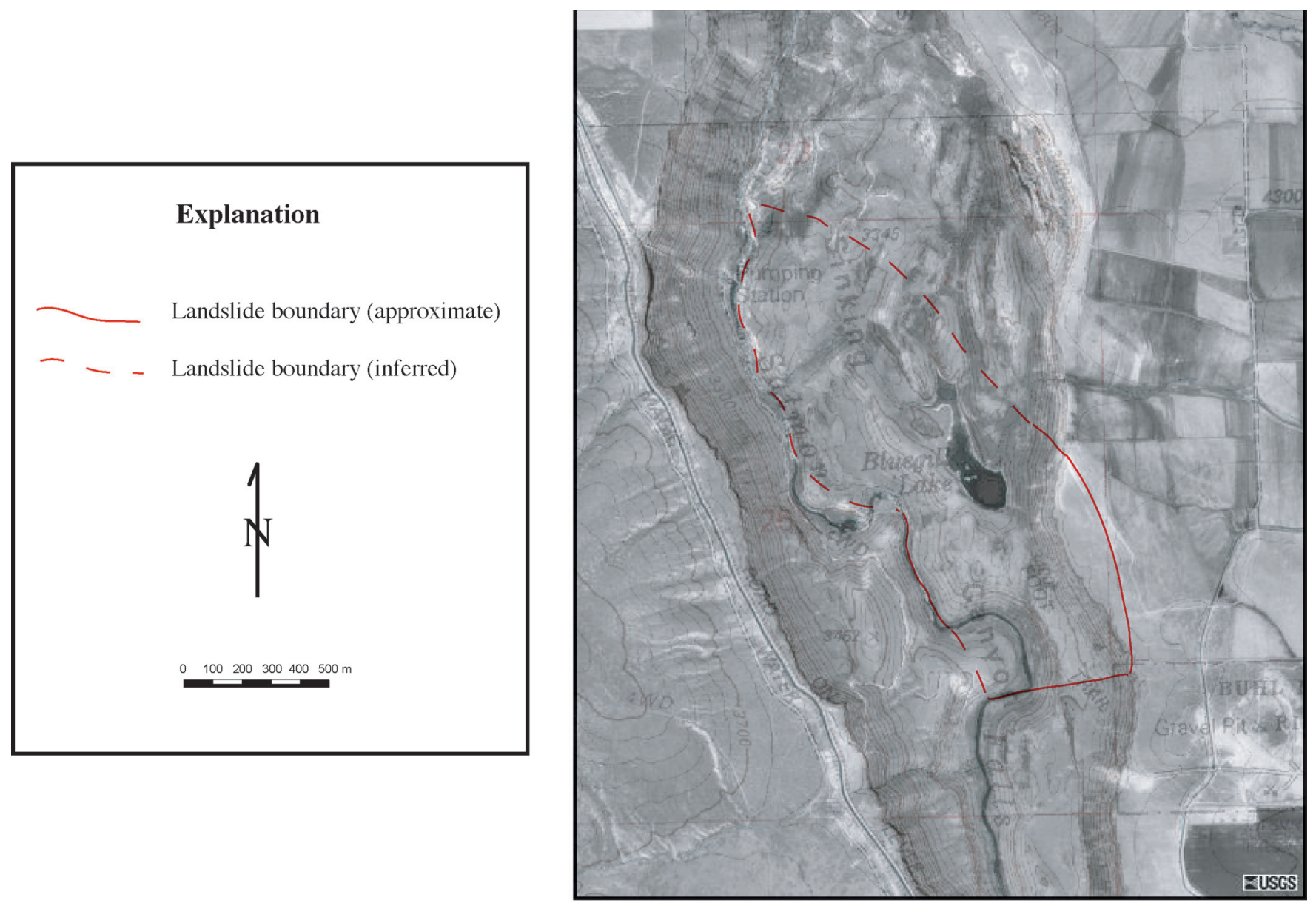

Figure 4. Map showing approximate boundaries of Bluegill landslide based on 24 September 2003 field reconnaissance and monitoring results. Base map consists of the USGS Balanced Rock topographic quadrangle dated 1 July 1987, superimposed on a vertical aerial photograph taken 16 May 1992. Note that Bluegill landslide dam and impounded lake were not present on date of the photograph.

decreasing to the south. Thus, the landslide headscarp exhibits a scissor type of motion. The upward movement of the landslide toe has resulted in the formation of a landslide dam that currently impounds a lake approximately $2 \mathrm{~km}$ long by 40 $m$ wide (Chadwick and others, in press). The toe of the slide has also encroached on Salmon Falls Creek downstream of the dam, and in places has caused realignment of the stream channel and minor impoundments of water.

According to the landslide classification system of Varnes (1978) and Cruden and Varnes (1996), the Bluegill landslide can probably best be classified as a rock slump or rock slide. The basalt cliffs in the area are also subject to local rock fall.

\section{Local Geology}

The Sinking Canyon area is located within the Owyhee Plateau near its northeastern boundary with the eastern Snake River Plain. Malde (1991) describes the Owyhee Plateau as an upland volcanic terrain consisting of rhyolite that is thinly veneered with basalt.

A reconnaissance geologic map of the west-central Snake River Plain (Malde and others, 1963) identifies the basalt unit that forms the canyon rim at the Bluegill landslide site as the upper part of the Banbury Basalt (fig. 5). The underlying geologic unit is mapped as the middle part of the Banbury Basalt, and is described as consisting largely of sand and pebble gravel in lenticular channel deposits, but including light-colored silt, clay, and diatomite in lake deposits. Just to the north of Sinking Canyon, these sediments are mapped as a thin unit that overlies the Idavada Volcanics, which are described as consisting chiefly of thick layers of devitrified welded tuff with some bedded vitric tuff and lava flows. Within the Sinking Canyon area, the thickness of the middle Banbury Basalt sediments is uncertain because the landslide debris obscures the underlying geologic units. It may be that the underlying sediments are thicker in the Sinking Canyon area than they are to the north, and that it is failure within 


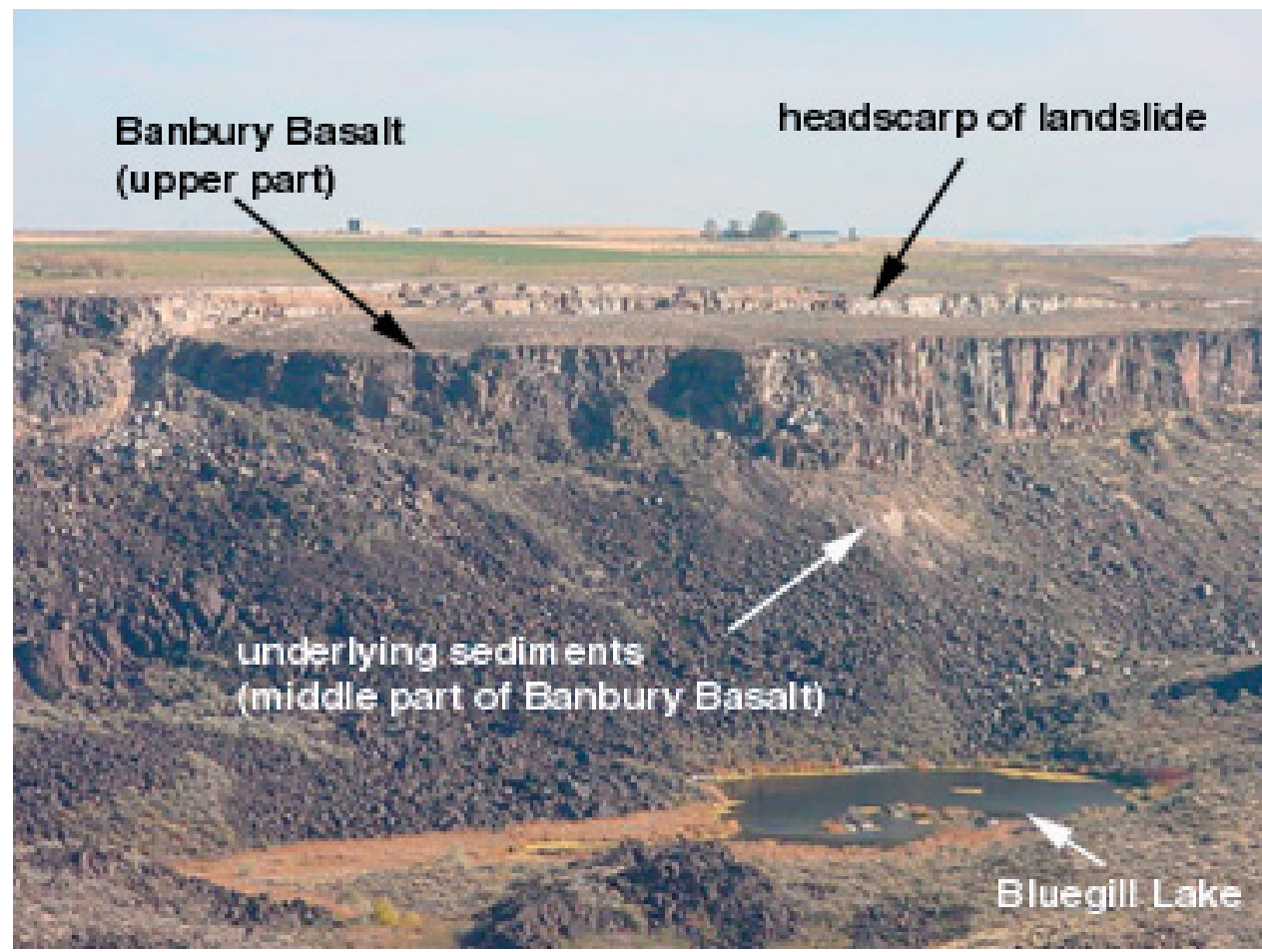

Figure 5. Photo of the upper portion of the Bluegill landslide taken from the west side of the canyon in November 2000. View is to the southeast. Length of the canyon rim that is visible in photo is about $600 \mathrm{~m}$. The upper part of the Banbury Basalt that forms the canyon rim and an outcrop of the underlying sediments of the middle part of the Banbury Basalt are labled. The headscarp of the landslide and Bluegill Lake are also identified. Photo courtesy of Karen Shilling, BLM.

the thicker, weak sediments that has resulted in the past and current landslide activity in Sinking Canyon.

\section{Recent Movement History}

The timing of the most recent movement of the Bluegill landslide is uncertain, but based on public reports to the BLM it is believed that the movement probably began in late 1998 or early 1999, (K.F. Shilling, BLM, 2001, oral commun.). Initial movement during the recent activation was relatively rapid, with a 4.5 ha (11 acre) area of the canyon rim moving downward an estimated 6-8 $\mathrm{m}$ and moving laterally several meters over a period of several months to a year. Remote-reading extensometers placed across the headscarp of the landslide in January 2001 by the USGS indicated that the upper part of the slide was moving about $10-15 \mathrm{~cm}$ per month during most of 2001. Total station surveys of prisms placed on the landslide (fig. 6), which were begun by the BLM in July 2001, indicated similar movement rates for the upper and lower parts of the slide through November 2001, with noticeable slowing of slide movement in late 2001 (fig. 7). From about November 2001 through mid-2003 the prism survey data indicate average movement rates of 2-4 cm per month. GPS data obtained during the February - May 2003 time frame indicate landslide movements of less than a centimeter per month (Chadwick and others, in press). Thus, the available data and observations indicate that the slide probably began moving in late 1998 or early 1999 , moved relatively rapidly (several meters) over a period of about 1 year, began slowing in late 2001, and is now continuing to move at a rate of less than a centimeter per month.

\section{Potential Causes of Landslide Activity}

The cause of the recent landslide movement is unknown, but increasing ground-water levels are often responsible for initiating slope failures by increasing pore-water pressures, thus decreasing the shear strength of soil and rock. The Bluegill landslide is located near the boundary of the Snake River Plain and the Owyhee Plateau, which comprises the southwest highlands of Idaho. Meteorological data available from the Western Region Climate Center (www.wrcc.dri.edu) for the southwest highlands of Idaho over the past 100 years indicate that annual precipitation in the area averaged about $300 \mathrm{~mm}$ (12 in) per year (fig. 8). Beginning in the early 1980s, however, there are periods of much higher than normal precipitation, with some yearly precipitation exceeding $400 \mathrm{~mm}$ (16 in). The 4-year period from 1995 through 1998 was unusually wet, with annual precipitation ranging between 400 and $530 \mathrm{~mm}$ (16 and $21 \mathrm{in}$ ). In contrast, the period from 1999 to present has been dry, with annual precipitation less than the 100 -yr average. A similar 100 -yr precipitation pattern is also observed for the central plains of Idaho, just to the north of the study area, although precipitation amounts are less and periods of higher than normal precipitation began in the 1960s. Therefore, it is likely that ground-water levels in the Bluegill landslide area were near their highest point in the past 100 years at about the time of the most recent landslide movement.

Whether or not the recent climatological change, specifically the unusually wet period in the latter part of the 1990s, was a factor in initiating the recent landslide movement cannot be stated for certain, but could well be a contributing factor. Annual precipitation during the 1930s was not unusually 


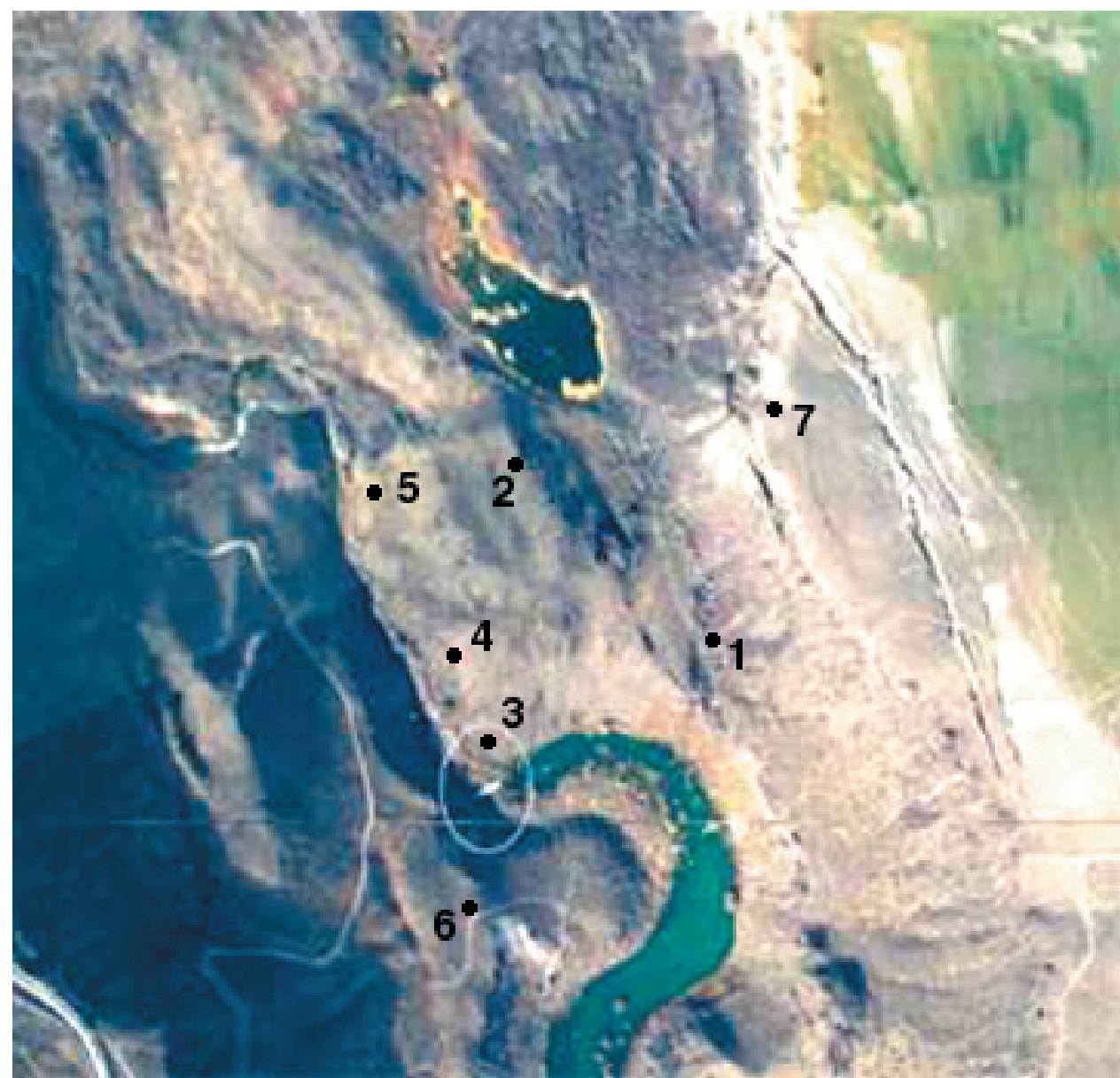

Figure 6. Aerial photo of Bluegill landslide showing locations of survey prism reflectors used in plots of landslide movement shown in figure 7. Area where uplift of toe of landslide has created landslide dam is circled. Photo courtesy of Karen Shilling, BLM.

\section{Assessment of Current Hazard}

\section{Landslide Dam Failure}

\section{Recent movement of the}

Bluegill landslide has created a landslide dam that forms a lake that is approximately $2 \mathrm{~km}$ long and averages about $40 \mathrm{~m}$ wide (Chadwick and others, in press). The dam (fig. 9) has been formed primarily by uplift of the canyon floor at the southern boundary of the slide, rather than by closing of the stream channel due to horizontal movement of the landslide. To the north, and just downstream from the dam, horizontal and upward movement of the toe of the landslide have narrowed the stream channel, and in some places have caused realignment of the stream and created small impoundments of water (fig. 10). The primary hazard currently associated with the landslide is a possible breach of the landslide dam that could cause flooding and outburst debris flows downstream from the landslide. The worst-case scenario would be a sudden and catastrophic failure of

high, so climatological conditions would not appear to be an obvious factor in the 1937 Sinking Canyon landslide activity. Other factors, such as irrigation or ground-water withdrawal, could also contribute to ground-water fluctuations in the area. The land affected by the 1937 Sinking Canyon activity was under cultivation at the time, and was presumably irrigated by surface water. Irrigation practices, or any changes in the amount of land under irrigation in the vicinity of the landslide, are unknown to the authors. Annual fluctuations in the level of Bluegill Lake, located on the landslide, have been observed (K.F. Shilling, BLM, oral commun., 2001) but there have been no quantitative or long-range observations to indicate that recent water levels in the lake were unusual. Note that the Sinking Canyon and Bluegill landslides are on the eastern side of the canyon, and that it is predominantly land on the east side of the canyon that is subject to irrigation (fig. 1 and fig. 4). This observation suggests that irrigation may play a role in initiating and maintaining landslide activity. A correlation between irrigation and initiation of landslides has been noted in other similar localities (Schuster and others, 1989, Chleborad and Schuster, 1995). the landslide dam, resulting in a release of all or most of the impounded water over a short period of time.

The amount of water impounded by the landslide dam has been estimated by Chadwick and others (in press) to be as much as $1,000,000 \mathrm{~m}^{3}$. However, two depth measurement transects of the lake conducted in November 2001 (K. Weinner and J. Tharp, BLM, written commun., 2001), indicated that $50 \mathrm{~m}$ upstream of the dam the mean lake depth was $2.3 \mathrm{~m}$, and that about $400 \mathrm{~m}$ upstream of the dam the mean lake depth was $4.5 \mathrm{~m}$. Because the lake becomes shallower with greater distance upstream, the average depth of the lake over its entire $2 \mathrm{~km}$ length would probably be on the order of 2-3 m or less. Based on the two stream transects, the BLM estimated the lake volume in November 2001 , to be a little over $260,000 \mathrm{~m}^{3}$. From late 2001 to mid 2003 , the toe of the slide moved upward less than $0.6 \mathrm{~m}$. (fig. 7b), or about 15 percent of the current dam height. Assuming that the lake depth increased by a corresponding amount during this time period and that the lake did not widen significantly in the narrow canyon, the volume of the lake probably did not increase by more than about $15-25$ 
A

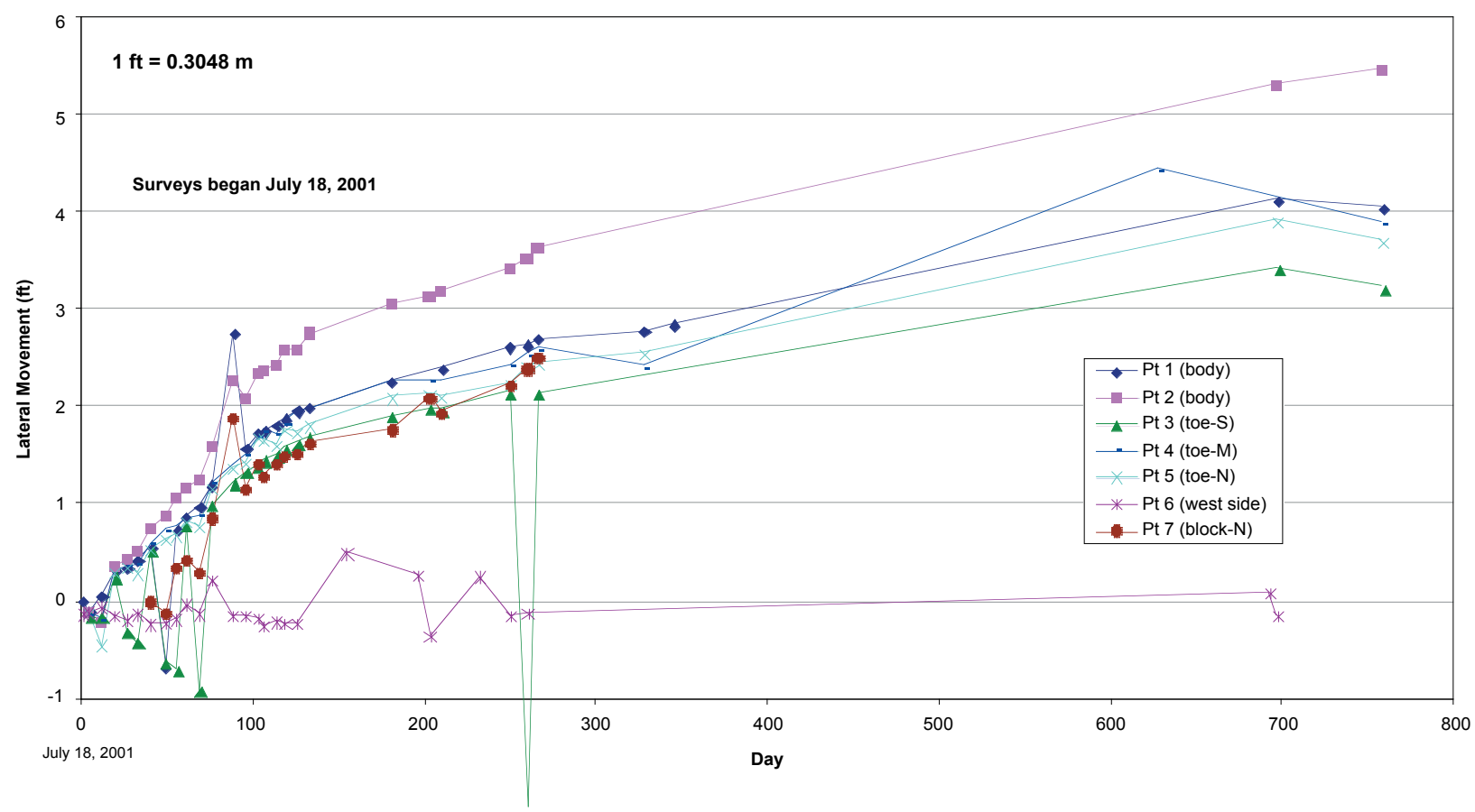

B

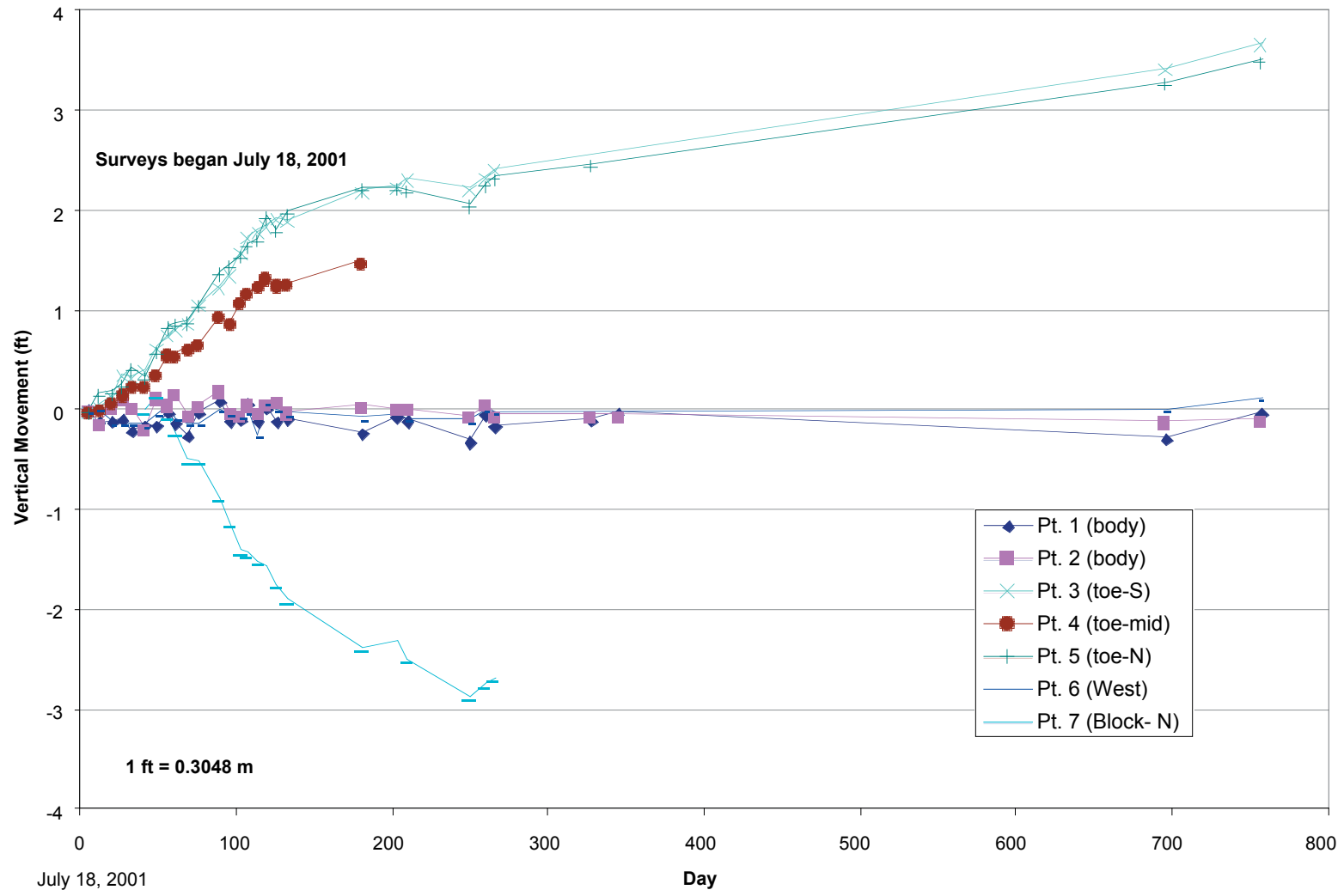

Figure 7. Plot of A, horizontal movement; and B, vertical movement; as determined from repeat surveys of reflector prisms begun on July 18, 2001. Locations of survey points are shown in figure 6. Data plots courtesy of Karen Shilling (BLM) and Stephen Dorsch (Idaho State University). 


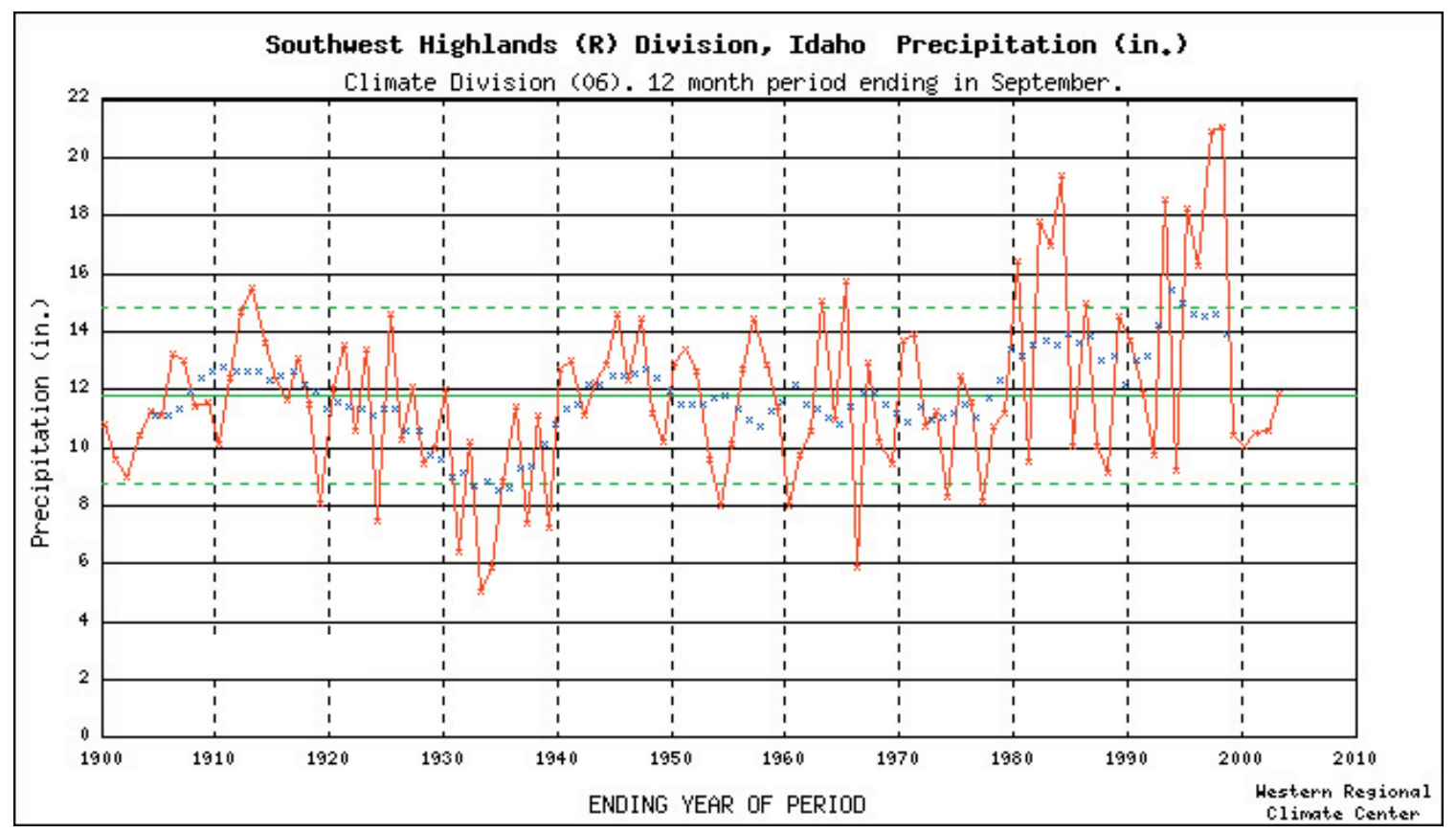

Figure 8. Plot of yearly precipitation for the southwest highlands of Idaho from 1900 through 2002. Red symbols indicate total precipitation for 12-month periods ending in September. Blue symbols are the 10-year running mean precipitation. Green lines represent the average precipitation and standard deviation for the period. Note the years of high precipitation in the later part of the 1990s, which produced the highest 10year running means of precipitation since 1900. (Data plot from Western Region Climate Center web site, www.wrcc.dri.edu/divisional.html).

percent. It is therefore inferred that the volume of the lake is actually about $325,000 \mathrm{~m}^{3}$.

Examination of the landslide dam indicates that it consists primarily of large boulders ranging in size from several centimeters to up to about a meter in diameter in a matrix of fine material (fig. 9). The fines are apparently derived from the sedimentary deposits underlying the upper basalt flow and are now intermixed with the basalt to form the bulk of the landslide deposit. Stream deposits in the canyon also contribute to the observed fines. Movement of the toe of the landslide has caused a portion of the old stream channel just below the dam to be uplifted several meters (fig. 9a). Uplift of the old streambed reveals fine-grained stream deposits about a meter thick on the east side of the current stream channel.

Where water from the impounded lake flows over the landslide dam, the streambed sediments and fine matrix material have been eroded away, leaving only the large boulders. As can be seen in figure 9, there has been some minor erosion of the dam, probably as a result of the removal of the fine matrix material by running water. The relatively small amount of downcutting into the dam indicates that boulders make up a sufficient volume of the dam for it to be "self armored" against erosion, and that sudden erosion and breaching of the dam is unlikely.
The total width and shape of the landslide dam parallel to the stream has not been determined. However, the BLM transects showed that $400 \mathrm{~m}$ upstream of the dam the lake was deeper $(7.2 \mathrm{~m})$ than at $50 \mathrm{~m}$ upstream of the dam $(5.3$ $\mathrm{m})$. This indicates that the dam is a relatively broad feature formed by uplift of the streambed. BLM field notes also indicate a transition from shallower to deeper water about $175 \mathrm{~m}$ upstream from the dam, with the deeper water occurring on the upstream side of this boundary. This observation also supports the idea that the dam is a relatively broad feature and that the narrow part of the dam visible above water level is where the greatest amount of uplift has occurred. Because the total uplifted area that forms the dam is apparently much broader than the visible part of the dam, and because of the large amount of coarse material that forms the dam, a rapid dam failure with sudden release of all of the impounded water is considered unlikely by the authors. A longitudinal profile of depth to the bottom of the stream channel would help to confirm the width and cross-sectional shape of the dam.

Another area of concern is that continued movement of the toe of the landslide downstream from the current dam, especially at rates like occurred early in the recent movement, could potentially dam the stream channel and create a larger and deeper lake than currently exists. However, because the toe of the active landslide is quite 

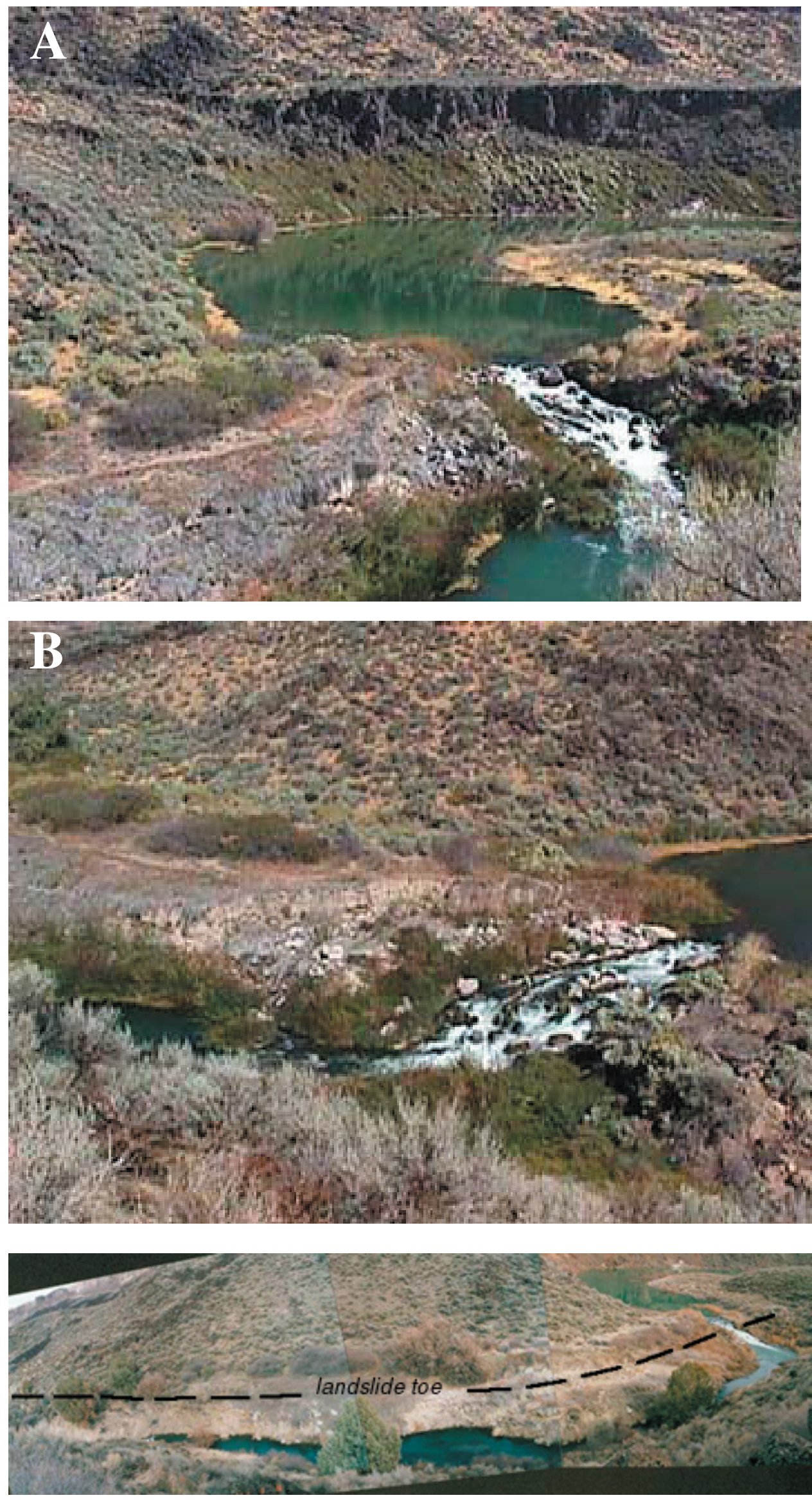

Figure 9. Photos of landslide dam formed by uplift of the toe of the Bluegill landslide. A. View to the southeast. Dam is on the south, or upstream side of the landslide and is approximately 3-4 $m$ in height. Note the old stream channel to the left of the dam (northeast side of channel) that has been uplifted by the landslide. B. Close-up view of landslide dam looking toward the northeast. Dam is composed primarily of large boulders of basalt. Some erosion of the dam has occurred due to stream downcutting. Photo taken September 24, 2003.
Figure 10. Composite of photographs taken March 2001 showing toe of landslide encroaching into Salmon Falls Creek downstream of the landslide dam. View is from west to east. Photo composite courtesy of Karen Shilling, BLM. 


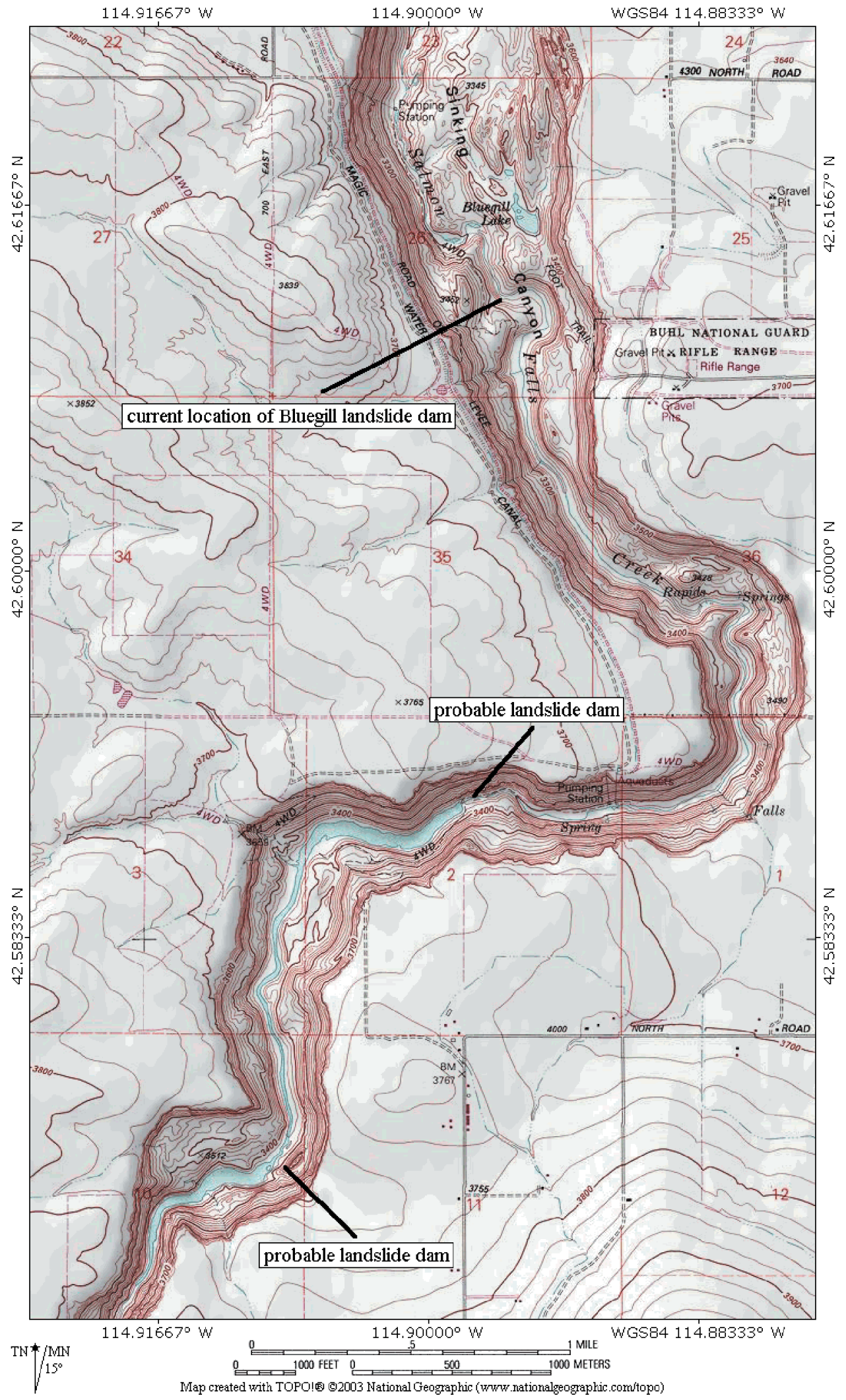

Figure 11. Topographic map of section of Salmon Falls Creek canyon showing old landslide dams approximately $4 \mathrm{~km}$ and $7 \mathrm{~km}$ upstream of Sinking Canyon and the Bluegill landslide. Ages of these older dams are uncertain. The topographic map (Balanced Rock 7.5-minute Quadrangle, USGS) was compiled in 1987. The sizes of the impounded lakes are similar to the size of the lake now formed behind the Bluegill landslide. 


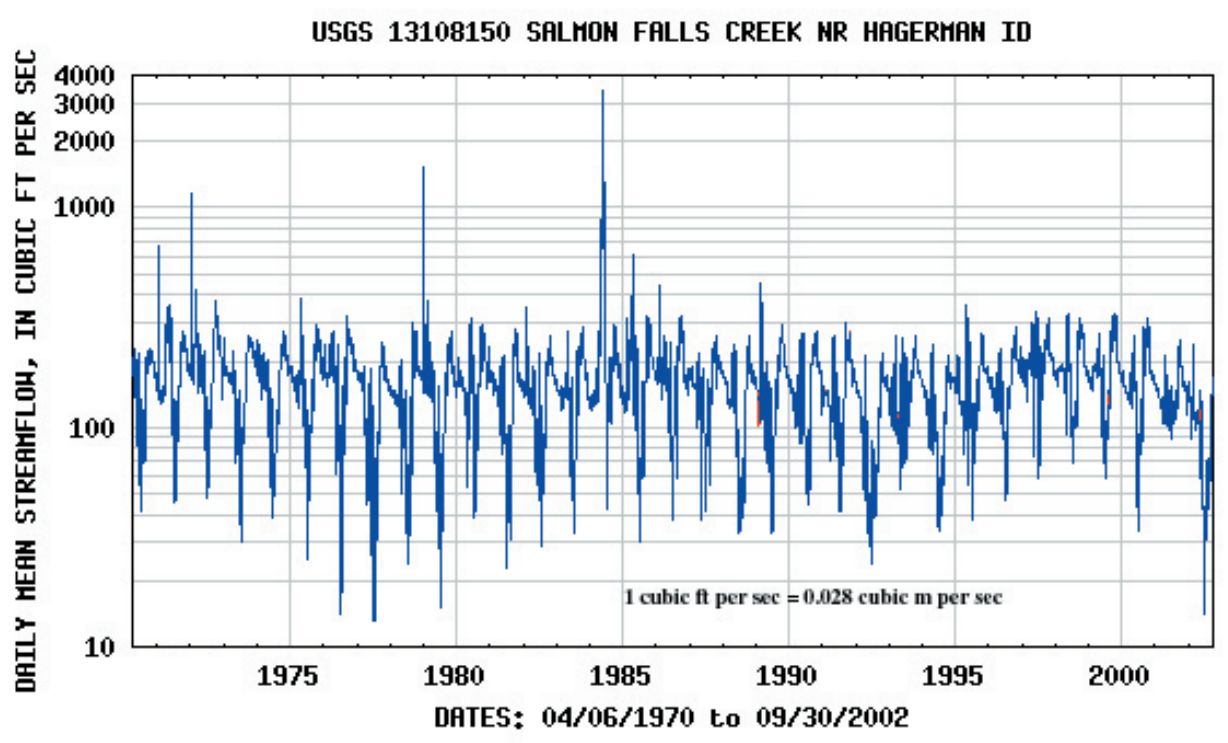

EXPLANATION

— DAILY MEAN STREAMFLOH _ ESTIMATED STREAMFLOH

Figure 12. Daily mean stream flow of Salmon Falls Creek between 1970 and 2003 at USGS gaging station approximately $10 \mathrm{~km}$ downstream from the Bluegill landslide. (Data plot from USGS web site http://nwis.waterdata.usgs.gov/id/nwis/discharge).
0.85 and $8.5 \mathrm{~m}^{3} / \mathrm{sec}$ (30 and $300 \mathrm{cfs}$ ) (fig. 12). The seasonal streamflows have remained fairly constant over the 32-year period of record, and only rarely has the maximum daily-mean streamflow exceeded $11 \mathrm{~m}^{3} / \mathrm{sec}$ (400 cfs). The maximum meandaily streamflow during the $32-$ year recording period was about $100 \mathrm{~m}^{3} / \mathrm{sec}(3500 \mathrm{cfs})$ in early 1984. Because of the regulating effect of Salmon Falls Dam, there is a low probability of an abnormally high stream-flow event impacting the Bluegill landslide dam.

A simplified dam-break simulation was conducted by the BLM (K. Gebhardt, BLM, written commun., 2001) using the FLDWAV model developed by the National Weather Service (http://weather.gov/oh/hrl/ rvmech/fld_avail.htm). The simulation was done for dam wide, the breadth of such a dam would be large compared to its height. The dam would also be composed of the same erosion-resistant material as the current dam, such that rapid erosion and down cutting would therefore not be expected.

Some indication of the future stability of the Bluegill landslide dam can be inferred from other landslide dams in this area of the canyon. Examination of the USGS Balanced Rock quadrangle topographic map (dated July 1, 1987 ) indicates two apparent landslide dams within about $7 \mathrm{~km}$ upstream of the Bluegill landslide (fig. 11). These topographic landforms are typical of the landslide features in Sinking Canyon. While the ages of these landslide dams are not known, they at least occurred prior to July1987, and are probably much older. The impoundments behind these older dams are similar in size to the Bluegill landslide impoundment, and their presence indicates that landslide dams formed in this geologic environment and topographic terrain may remain stable for many years. The ages of these older landslide dams could perhaps be better constrained by researching old maps and county records.

The flow of Salmon Falls Creek is regulated to some degree by Salmon Falls Dam, located about $50 \mathrm{~km}$ upstream of the landslide. The dam was built in 1911 (C. Skinner, Idaho Department of Water Resources, Southern Region, oral commun., 2003). USGS streamflow records since 1970 for Salmon Falls Creek near Hagerman, about 10 $\mathrm{km}$ downstream of the landslide, indicate that seasonal variations in daily-mean streamflow generally vary between heights of 4.5, 6.0, and $7.6 \mathrm{~m}(15,20$, and $25 \mathrm{ft})$ using two different times to reach maximum breach (12 and $30 \mathrm{~min}$.). A width of breach of $15 \mathrm{~m}(50 \mathrm{ft})$ was used in the simulation. The actual height of the Bluegill landslide dam on its

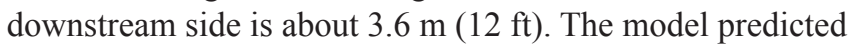
discharge at specified distances downstream from the

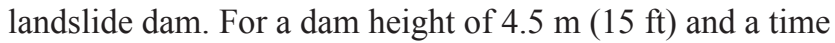
to maximum breach of 12 minutes, the simulation predicted peak flows less than $85 \mathrm{~m}^{3} / \mathrm{sec}(3000 \mathrm{cfs})$ at a distance 10 $\mathrm{km}$ (13 km measured along the stream channel) downstream from the dam. Thus, based on the FLDWAV model simulation, peak flow from a rapid breach of the current dam would produce a flow rate at the USGS gaging station that is less than the 30-yr maximum flow measured in 1984.

According to information provided by BLM (K. Shilling, written commun., 2003), a 1984 newspaper account indicates that high water from Salmon Falls Creek did spread out over the flood plain below the mouth of the canyon. Apparently no homes were present on the flood plain at that time, but 10-15 homes are now located on or near the flood plain. It is therefore possible that sudden failure of the Bluegill landslide dam could cause flooding of these structures. Also, if high water similar to what occurred in 1984 were to cause sudden failure of the dam, then flows could be about double those measured in 1984. Such flows would have the potential to produce downstream flooding.

The current rate of movement of the Bluegill landslide, the apparent breadth and composition of the landslide dam, the 
long history of relatively stable flow rates of Salmon Falls Creek, and the presence of older landslide dams in the same vicinity of the canyon all provide strong indications that a sudden and massive failure of the Bluegill landslide dam is unlikely. The dam-break simulation, although a simplified analysis, also suggests that a rapid breach of the dam would not produce flows greater than have occurred in the past 30 years at downstream locations where people or structures are located.

\section{Other Landslide Hazards}

Recent movement of the Bluegill landslide has created large, linear-trending open fissures on the 4.5 ha area of downdropped canyon rim. This area probably also contains open fractures that are bridged by soil and are thus not visible at the ground surface. Some of these fractures likely reach depths of several tens of meters.

The 50-80 m thick basalt flow that forms the upper canyon rim also contains numerous open fractures associated with jointing planes behind the exposed cliff face. These fractures have been widening with progressive landslide movement, making the cliff face highly unstable. Areas below the cliff, including the trail to Bluegill Lake, are therefore exposed to significant risk from rock fall, as are areas of the cliff used by recreational rock climbers. Such hazards in the 4.5 ha area above the canyon rim affected by the landslide and the areas along and below the canyon rim pose a significant safety threat to hikers and climbers, as well as wild or domestic animals.

\section{Future Considerations}

Movement of the landslide has slowed dramatically in recent months, but the possibility of a future acceleration of movement cannot be ruled out. Any significant increase in movement rates would result in an increase in the size and depth of the existing landslide-formed lake, either by continued uplift of the existing dam and/or closing off of the stream channel below the dam. As discussed above, such a scenario would not necessarily increase the likelihood of a dam failure. However, the potential consequences of a failure of a much larger landslide dam would be more severe. As such, movement of the landslide should be carefully monitored until it is apparent that the landslide has stabilized. Thereafter, periodic visual inspections and annual surveys of prism locations should be done to confirm that the landslide remains stable, especially during the spring and early summer months when ground-water levels may be at seasonal highs and irrigation of nearby cropland is in progress.

\section{Mitigation Options}

It is highly unlikely that actions taken to prevent the movement or possible future movement of the landslide would be financially feasible. However, mitigation options focused on eliminating or reducing the impacts of hazardous events that could potentially result from movement of the landslide are less expensive and much more likely to be cost effective than efforts to prevent landslide movement. The most serious hazard associated with the landslide is downstream flooding, and/or debris flows, that might occur in the event of a sudden failure of the current or any future landslide dam. The only viable option for elimination of this potential hazard is to drain the impounded water from behind the dam.

Draining of the landslide-formed lake could be achieved relatively inexpensively by lowering the height of the landslide dam. Heavy equipment, such as a track-mounted excavator or bulldozer, could be used to gradually excavate the dam to a level near the original stream elevation. Dam material would need to be removed in small stages to prevent rapid flow and incision of the dam by the escaping water. Any significant future movement of the landslide would likely require additional excavation. An existing road from the west side of the canyon currently provides access into the canyon near the dam, and a short access road to the dam could easily be cut by bulldozer if necessary. Costs for conducting such an excavation of the dam would probably be less than $\$ 10,000$. The only other feasible option to drain the lake would be to construct a large-diameter siphon tube to carry water around the area of the canyon affected by the landslide. Such an action, however, would be extremely costly and would require that the tube pass along the west side of the canyon to avoid damage from future landslide movement. This option is considered impractical considering the high cost and the current low probability of rapid dam failure.

Another option, in lieu of draining the lake, would be to control the lake level by constructing an irrigation pumping station upstream of the dam. A pumping station currently exists a short distance downstream of the landslide that diverts water into an irrigation canal on the west canyon rim. This pumping station could be threatened by future landslide movement, or lost in the unlikely event of a landslide dam failure. Relocation of the pumping station upstream of the dam would eliminate that risk and provide a means of controlling the amount of water behind the landslide dam. It is our understanding that the land on the west side of the canyon is under BLM management. The possibility and feasibility of a BLM/private sector cooperative funding project to relocate the pumping station upstream of the landslide dam should be explored. Although more costly than draining the lake, such an arrangement could benefit the BLM in mitigating the potential hazard by routing some of the Salmon Falls Creek flow around the landslide dam. Depending on the pumping capacity, such a pump station could be used to regulate the 
level of water behind the dam, especially during periods of high flow in Salmon Falls Creek. At the same time, private sector irrigation concerns could also benefit by having an alternate source of irrigation water not threatened by the Bluegill landslide. A canal to carry the pumped water currently exists on the west rim of the canyon, and if necessary the diverted water could be returned to Salmon Falls Creek downstream from the landslide.

Because a rapid failure of the landslide dam is considered unlikely, the authors do not believe that elaborate or expensive mitigation actions are warranted. As longer term options are investigated, current mitigation efforts should focus on continued monitoring of landslide movement and periodic inspections of the landslide dam. An expansion of the current monitoring effort is warranted, and investigations should be undertaken to better define the boundaries of the currently active slide. Public access to the active areas of the landslide should be restricted, or at least warnings of the potential dangers of entering the area should be clearly posted. The following options for continued monitoring and investigation of the landslide are suggested:

1. Continue cooperative effort with researchers at Idaho State University to monitor the landslide using remote-sensing techniques. Specifically, continue the efforts to utilize InSAR and LiDAR data to develop DEM models of the slide and to delineate slide boundaries. Establishment of a baseline DEM will allow for changes in landslide topography due to slide movement to be quantified from future LiDAR and InSAR surveys.

2. Continue the in-place GPS monitoring currently being conducted by Idaho State University. At a minimum, try to maintain two GPS stations along the toe of the slide, one station in the middle area of the slide, and one station on the top of the upper block of the slide. If additional GPS receivers can be acquired, deploy one to the north and one to the south of the observed displacement to help delineate the active part of the landslide. This monitoring should be continued for an additional 1-2 years unless displacement ceases. If movement continues beyond 2 years, then the need for continuing the GPS monitoring should be reassessed.

3. If the additional GPS stations discussed above are acquired and deployed, then the periodic movement surveys of prism locations on the landslide could be discontinued. Otherwise, it is suggested that additional survey monuments be installed to define the boundaries of active landslide movement, and that the surveys of the established and new monuments be continued on 2-month intervals. The movement surveys should be conducted on a more frequent basis in the event of an increase in the rate of landslide movement.

4. The geology of the landslide area should be mapped in detail. Of particular importance would be the determination, if possible, of the thickness of the underlying sedimentary rocks. It would also be helpful to determine if the volcanic rocks that outcrop in the canyon just upstream of the landslide are in-place, or are derived from the upper canyon rim by landsliding.

5. Continue near real-time monitoring of movement across the headscarp of the landslide using a cellphone equipped datalogger in order to provide early notification in the event of accelerated landslide movement. The GPS monitoring provides better overall indication of slide movement, but because the data is collected and processed every 2-3 weeks, it does not provide an early-alert capability.

6. Although rapid failure of the landslide dam is considered unlikely, the phone numbers and contact information compiled by BLM for the few residences and businesses located within the floodplane downstream of the landslide should be kept current and made available to local emergency officials. If not already in existence, a plan should also be developed to notify emergency officials to evacuate potentially affected downstream parties should a dam failure occur or appear imminent.

The following actions are also considered desirable should funding support be feasible. While these actions would greatly enhance the landslide monitoring effort and result in an improved understanding of the causes and potential behavior of the landslide, they are not considered essential with respect to the current level of hazard.

1. Contract for real-time GPS monitoring of the landslide movements. Real-time GPS monitoring and alarm services, including installation of the remote GPS stations, are commercially available. Such services tend to be costly, but offer the advantage of real-time data acquisition and alarming capability via the Internet. Depending on the number of GPS receivers, the cost of real-time GPS monitoring of the Bluegill landslide are estimated to be between $\$ 50,000$ to $\$ 75,000$ for capital equipment purchases and $\$ 20,000-\$ 25,000$ per year for a services contract. Such real-time monitoring would eliminate the need for other remote monitoring and periodic prism surveys, and as such, some of these costs would be recovered by BLM salary and equipment cost savings from no longer having to conduct labor intensive and time consuming periodic movement surveys. 
2. Expand the existing cell-phone based monitoring system to include deformation monitoring at the toe of the slide and instrumentation to detect changes in water level or flow below the dam. Hardware for expanding and upgrading the current system to provide a network of additional monitoring instruments would cost an estimated $\$ 15,000-\$ 20,000$. Monthly cell phone charges to collect the data and provide a pager alert in the event of significant changes are estimated at less than $\$ 35$ per month.

3. Drill a $150-200 \mathrm{~m}$ deep exploratory boring just east of the landslide headscarp to determine the geologic stratigraphy in this part of the canyon, and to monitor long-term ground-water pressure variations that likely play a critical role in triggering and maintaining landslide movement. Data from such a boring would be essential to establish a better understanding of the landslide and thus provide a basis for forecasting its long-term behavior. Construction of an exploratory boring and monitoring well would likely cost $\$ 50,000$ $\$ 75,000$. Data collection could be integrated with the existing cell-phone based monitoring system at the landslide site.

\section{Summary}

The most significant hazard posed by the Bluegill landslide is a rapid failure of the landslide dam that could produce catastrophic flooding, and possibly debris flow from entrainment of channel debris in the flood waters. Some residences and structures located in the Salmon Falls Creek drainage beginning at a distance of about $10 \mathrm{~km}$ downstream from the landslide could be at risk should flooding occur. However, based on the available information and a visual inspection of the landslide, the authors do not believe the current landslide dam poses an imminent risk.

The landslide dam is a relatively wide feature caused by uplift of the canyon floor and streambed. The breadth (stream parallel width) of the dam imparts stability that makes a sudden failure improbable. The dam is composed primarily of large boulders of volcanic rock, and thus does not appear vulnerable to rapid erosion. The dam has not increased in size significantly since the landslide movement dramatically slowed in late 2001. Some erosion of the dam by Salmon Falls Creek is visible, and the level of water behind the dam has apparently decreased somewhat over the past several months (K.F. Shilling, BLM, oral commun., 2003). The presence of two impoundments of similar size from apparent landslide dams upstream of the Bluegill landslide indicate that such features are not uncommon in this part of the canyon. Because these landslide dams have been present for at least 16 years (fig. 11), and perhaps much longer, suggests that they are stable for the flows that typically occur in Salmon Falls Creek, and we believe that the Bluegill landslide dam is probably equally stable.

Results of a simple dam-burst simulation indicates that a rapid failure of the existing dam would produce flows 10 $\mathrm{km}$ downstream that are equivalent to or less than the 30year maximum flow recorded at that location. Although this simulation can only be considered a rough approximation of expected flows, it does suggest that flows from a rapid dam failure would probably not exceed the highest seasonal flows measured over the past 30 years, unless the dam were to fail during a rare period of equivalently high seasonal flows.

Continued or sudden renewed movement of the landslide may increase the height of the dam, but would also likely increase or maintain the breadth of the dam. Renewed landslide movement could also choke off the stream channel below the existing dam and create a much broader dam that would be composed of similar erosion-resistant materials as the existing dam. Impounded water would eventually overtop the dam and flow over the landslide, ultimately creating a new stream channel. However, rapid erosion of such a potential dam would also be highly unlikely.

Other hazards associated with the landslide derive mainly from the presence of wide, deep fissures on the 4.5 ha upper block, and from rockfall from the cliff that forms the canyon rim. Closing the area to public access would effectively mitigate these hazards, but if closure of the area is not an option, then warnings of the hazards should be clearly posted at key locations around the site.

\section{References}

Chadwick, J., Thackery, G., Dorsch, S., Glenn, N., and Sklar, J., 2003, Use of GPS and interferometric SAR for monitoring a large landslide in south-central Idaho: Proceedings of the International Symposium on Remote Sensing of Environment, 30 ${ }^{\text {th }}$, November 10-14, 2003, Honolulu, Hawaii.

Chleborad, A.F., and Schuster, R.L., 1995, A protocol for monitoring movement and seepage conditions at the Hagerman Fossil Beds National Monument, south-central Idaho: U.S. Geological Survey Admin. Report, Denver, $\mathrm{CO}, 20 \mathrm{p}$.

Cruden, D.M., and Varnes, D.J., 1996, Landslide types and processes, in Turner, A.K. and Schuster, R.L., eds., Landslides - investigation and mitigation: National Res. Council, Transp. Res. Board Special Report 247, p. 3675.

Lee, C.A., 1938, Recent landslides in Idaho: Journal of Geology, 46(4), p. 660-665.

Malde, H.E., Powers, H.A., and Marshall, C.H., 1963, Reconnaissance map of west-central Snake River Plain, Idaho: U.S. Geological Survey Miscellaneous Geologic Investigations Map I-373, scale 1:250,000. 
Malde, H.E., 1991, Quaternary geology and structural history of the Snake River Plain, Idaho and Oregon, in Morrison, R.B., ed., Quaternary nonglacial geology; Conterminous U.S.: Boulder, Colorado, Geological Society of America, the Geology of North America, v. K-2, p. 251-281.

Schuster, R.L., Chleborad, A.F., and Hays, W.H., 1989, The White Bluffs landslides, in Galster, R.W., ed., Engineering Geology in Washington, Wash. Div. Geology and Earth Resources Bull. 78, v. 2, p. 911-920.
Varnes, D.J., 1978, Slope movement types and processes, in Schuster, R.L. and Krizek, R.J., eds., Landslidesanalysis and control: National Res. Council, Transp. Res. Board Special Report 176, p. 11-33. 